\title{
PARAMETER POPULASI KERAPU SUNU (Plectropomus sp.) DAN OPSI PENGELOLAANNYA DI PERAIRAN KARIMUNJAWA
}

\author{
Population Parameter of Coral Grouper (Plectropomus sp.) and Management Option In \\ Karimunjawa Waters
}

Oleh:

Siska Agustina ${ }^{1 *}$, Moh Natsir ${ }^{2}$, Menofatria Boer $^{3}$, Purwanto $^{4}$, Irfan Yulianto ${ }^{5}$

\author{
1Wildlife Conservation Society. sagustina@wcs.org \\ 2Puslitbangkan Kementrian Kelautan dan Perikanan.naseer.brpl@gmail.com \\ 3 Departemen Manajemen Sumberdaya Perairan,, FPIK-IPB.mboer@ymail.com \\ ${ }^{4}$ USAID SEA.purwanto.pp@gmail.com
}

5Wildlife Conservation Society dan Departemen Pemanfaatan Sumberdaya Perikanan, FPIK-IPB. iyulianto@wcs.org

*Korespondensi: sagustina@wcs.org

Diterima: 18 Desember 2017; Disetujui: 21 Mei 2018

\begin{abstract}
Groupers are important fisheries resources in the tropic and sub-tropic due to it has high economic value, so that continuously exploitation even in some waters have collapsed and high capture pressureThe study aimed to identify population parameters of coral grouper (Plectropomus sp.) in Karimunjawa waters as basic information for fisheries management. Sampling method using fish landing observation method for fish catches in 14 days every month since 2010-2015 caught in Karimunjawa waters. Growth parameters, mortality, length at first capture, and recruitment pattern analysis using the Rstudio, FiSAT II and spawning potential ratio with LB-SPR analysis. The growth rate is relatively slow with $k$ values ranging from 0.10 to 0.13 and lifespan of 21.93-27.73 years. The stock condition of the coral grouper species of $P$. leopardus, $P$. maculatus, and $P$. Oligacanthus was indicated overfished with E> 0.5 and SPR of 0.14, 0.22, and 0.25. These indicate that the 3 species of Plectropomus sp. in Karimunjawa is at unsustainable levels. Coral grouper type $P$. areolatus has $E=0.45$ and $S P R=0.52$, meaning that this type of grouper has a low exploitation rate and high spawning potential compared to other species coral grouper in Karimunjawa waters.
\end{abstract}

Keywords: coral grouper, fisheries, Karimunjawa waters, stock status

\begin{abstract}
ABSTRAK
Ikan kerapu adalah sumber perikanan penting di daerah tropis dan sub-tropis karena bernilai ekonomis tinggi, sehingga terus dilakukan eksploitasi bahkan beberapa perairan telah mengalami collapse dan tekanan penangkapan yang tinggi. Penelitian ini bertujuan mengidentifikasi parameter-parameter populasi ikan kerapu sunu (Plectropomus sp.) di perairan Karimunjawa sebagai informasi dasar dalam pengelolaan perikanan. Metode pengambilan data menggunakan metode observasi (pengamatan) terhadap hasil tangkapan ikan selama 14 hari dalam satu bulan dari tahun 2010-2015 yang ditangkap di Perairan Karimunjawa. Analisis parameter pertumbuhan, mortalitas, length first capture, dan recruitment pattern menggunakan program Rstudio, FiSAT II dan rasio potensi pemijahan dengan analisis LB-SPR. Laju pertumbuhan tergolong lambat dengan nilai k berkisar $0,10-0,13$ dan lifespan 21,93-27,73 tahun. Kondisi stok ikan kerapu sunu jenis $P$. leopardus, $P$. maculatus, dan $P$. oligacanthus diindikasikan mengalami kondisi tangkap lebih
\end{abstract}


dengan $E>0,5$ dan SPR sebesar 0,14, 0,22, dan 0,25. Hal ini menunjukkan bahwa penangkapan saat ini untuk 3 spesies kerapu sunu di Karimunjawa berada pada tingkat yang tidak berkelanjutan. Kerapu sunu jenis $P$. areolatus memiliki E sebesar 0,45 dan SPR 0,52, artinya kerapu jenis ini memiliki tingkat eksploitasi yang rendah dan potensi pemijahan yang tinggi dibandingkan jenis kerapu sunu lainnya di Perairan Karimunjawa.

Kata kunci: kerapu sunu, perikanan, Perairan Karimunjawa, status stok

\section{PENDAHULUAN}

Ikan kerapu merupakan salah satu sumber daya ikan penting di daerah tropis dan subtropis karena bernilai ekonomis tinggi. Setiap tahun lebih dari 8000 ton ikan kerapu senilai lebih dari 1 Milyar dolar Hong Kong diekspor dari Philipina, Indonesia, Malaysia, dan Australia untuk dikonsumsi di Hong Kong dan Cina (Yin 2014). Permintaan ikan komoditas tersebut di pasar internasional mendorong nelayan untuk meningkatkan upaya penangkapannya sehingga terancam kondisi tangkap lebih. Akibatnya stok ikan kerapu pada beberapa perairan telah mengalami collapse (Arreguin-Sanchez \& Pitcher 1999) dan tekanan yang cukup berat mengakibatkan overfishing (Sadovy 2005). Oleh karena, itu The International Union for the Conservation of Nature and Natural Resources (IUCN) Red List of Threathened Species tahun 2006 memasukkan beberapa jenis ikan kerapu seperti humpback grouper atau kerapu bebek (Cromileptes altivelis), estuary grouper atau kerapu lumpur (Epinephelus lanceolatus dan Epinephelus coioides) dan spotted coralgrouper atau kerapu sunu (Plectropomus leopardus) sebagai spesies yang terancam.

Upaya pelestarian stok ikan kerapu telah dilakukan dibeberapa daerah melalui penetapan kawasan konservasi perairan, salah satu diantaranya adalah Taman Nasional Karimunjawa. Kepulauan Karimunjawa (Surat Keputusan Menteri Kehutanan No. 74/Kpts-II/2001) merupakan kawasan konservasi yang mencakup ekosistem hutan hujan tropis daratan rendah (1.285,5 ha) dan wilayah perairan (110.117,3 ha) yang kaya akan sumber daya, terutama sumber daya ikan karang dengan keanekaragaman yang tinggi. Salah satu sumber daya penting di Kepulauan Karimunjawa adalah ikan kerapu (Yulianto et al. 2015). Ikan dari Famili Epinephelidae di Perairan Karimunjawa tahun 2015 merupakan ikan dengan presentase terbesar ke-3 sebesar 9\% setelah Family Scombridae sebesar 35\% dan Caesionidae sebesar 30\%.

Beberapa lokasi di TN Karimunjawa merupakan lokasi pemijahan ikan kerapu, terdapat tiga spesies ikan kerapu yang ditemukan di setiap lokasi pengamatan yaitu Epinehelus fuscoguttatus, Plectropomus areolatus, dan Plectropomus oligacanthus (Kartawijaya et al. 2007). Berdasarkan monitoring yang dilakukan oleh Wildlife Conservation Society, jenis ikan kerapu sunu yang terdata di Perairan Karimunjawa terdiri dari jenis Plectropomus areolatus (sunu hitam), Plectropomus laevis (sunu kasar), Plectropomus leopardus (sunu bintang timur), Plectropomus maculatus (sunu kuning), dan Plectropomus oligacanthus (sunu macan). Ikan kerapu yang dominan didaratkan di Karimunjawa berasal dari genera Cephalopholis sp., Epinephelus sp., dan Plectropomus sp. Ikan kerapu dari genus Plectropomus sp. atau dikenal dengan nama lokal kerapu sunu merupakan target utama penangkapan di Perairan Karimunjawa karena memiliki nilai ekonomis tertinggi (Yulianto et al. 2015). Ikan kerapu menurut Yulianto et al. (2013) ditangkap dengan menggunakan alat tangkap pancing ulur, purse seine, panah, troll lines, dan jaring insang.

Nilai ekonomis ikan kerapu yang tinggi yang mengakibatkan kegiatan penangkapan meningkat setiap tahun (Sadovy et al. 2003) menjadi salah satu dasar diperlukannya pengelolaan ikan tersebut untuk menghindari terjadinya penurunan stok sumber daya. Untuk keperluan pemulihan kesehatan stok dan pengelolaan perikanan diperlukan kajian pendugaan parameter-parameter populasi. Hasil estimasi parameter-parameter tersebut disajikan dalam tulisan ini. Penelitian ini bertujuan mengidentifikasi parameter-parameter populasi ikan kerapu sunu (Plectropomus sp.) di perairan Karimunjawa sebagai informasi dasar dalam pengelolaan perikanannya.

\section{METODE}

Penelitian dilakukan di Taman Nasional Karimunjawa, Jawa Tengah. Pengambilan contoh ikan kerapu sunu (Plectropomus sp.) di Perairan Karimunjawa dan sekitarnya dilakukan selama 14 hari setiap bulan mulai dari tahun 2010 hingga 2015. Spesies ikan yang diamati adalah seluruh jenis dari genus Plectropomus 
sp. yang didaratkan di Desa Karimunjawa. Pengukuran panjang dilakukan dengan menggunakan papan ukur berskala dan dilakukan dokumentasi. Data yang dikumpulkan adalah panjang total ikan (total length). Jumlah contoh setiap spesies disajikan dalam Tabel 1.

Parameter populasi ikan yang diamati diantaranya parameter pertumbuhan, umur harapan hidup (lifespan), mortalitas dan laju eksploitasi (pemanfaatan), panjang rata-rata ikan pertama kali tertangkap, panjang ikan pertama kali matang gonad, panjang optimum, pola rekrutmen, dan spawning potential ratio (SPR).

Parameter pertumbuhan ikan, panjang asimtotik $(L \infty)$, yaitu panjang maksimum ikan secara teoritis, koefisien pertumbuhan $(K)$ diduga menggunakan metode ELEFAN I dalam piranti lunak Rstudio (Sparre dan Venema 1999; Mildenberger et al. 2017), dan umur teoritis $\left(t_{0}\right)$ diduga dengan persamaan empiris Pauly (1984) sebagai berikut:

$$
\begin{aligned}
& \log -\left(t_{0}\right)=-0,3922-0,2752 \log \left(L_{\infty}\right)- \\
& 1,038 \log K \ldots \ldots \ldots \ldots \ldots \ldots \ldots \ldots \ldots \ldots \ldots \ldots \ldots \ldots \ldots
\end{aligned}
$$

Nilai $K$ dan to digunakan sebagai dasar untuk menduga lifespan (Pauly 1984) dengan persamaan sebagai berikut:

$$
\text { lifespan }=t_{0}+\left(\frac{2,996}{K}\right)
$$

Pendugaan mortalitas total ( $Z$ ) dilakukan dengan metode kurva konversi hasil tangkapan dengan panjang (length converted catch curve) pada program Rstudio (Pauly 1984; Mildenberger et al. 2017). Mortalitas penangkapan ( $F$ dan laju eksploitasi $(E)$ dihitung dengan rumus (Pauly 1984):

$$
Z=F+M \operatorname{dan} E=\frac{F}{Z}
$$

Panjang rata-rata ikan pertama kali tertangkap $(L c)$ dihitung dengan bantuan program Rstudio (Sparre dan Venema 1999; Mildenberger et al. 2017). Pendugaan panjang ikan pertama kali matang gonad $(L m)$ menggunakan persamaan Froese dan Binohlan (2000)dan panjang optimal (Lopt) menggunakan persamaan Beverton (1992) yaitu:

$$
\begin{aligned}
& \log L m=0,8979 * \log L_{\infty}-0,078 \\
& \text { Lopt }=1.0421 * \log L \infty-0.2742
\end{aligned}
$$

Pola rekrutmen ikan dianalisis dengan bantuan program FISAT II pada subprogram recruitment pattern untuk mengetahui kontruksi rekrutmen suatu runut waktu dari frekuensi panjang dalam menentukan puncak per tahun.
Untuk menghitung rasio potensi pemijahan atau Spawning Potential Ratio (SPR), biomass dihitung untuk setiap kelompok panjang dan "spawning stock biomass (SSB)":

$S S B=\sum_{t=t_{m}}^{t_{\lambda}} N_{t} x W_{t}$

dimana $W_{t}$ adalah rata-rata "weight-at-age". SSB dihitung pada tingkat "pristine" $\left(\mathrm{B}_{0}\right)$. Lalu SPR dihitung untuk tingkat LC dan $F$ yang berbeda, dengan membagi SSB yang dieksploitasi dengan SSB "pristine"

$$
S P R=\frac{S S B_{F}}{S S B_{F=0}}
$$

Pendugaan spawning potential ratio (SPR) dengan prinsip analisis diatas dilakukan dengan analisis online Length-based Spawning Potential Ratio mengacu pada Hordyk et al. (2014).

\section{HASIL}

\section{Parameter Pertumbuhan}

Hasil pendugaan parameter pertumbuhan ikan kerapu sunu di perairan Karimunjawa disajikan pada Tabel 2. Berdasarkan hasil analisis ikan kerapu sunu jenis Plectropomus maculatus memiliki panjang asimptotik $(L \infty)$ yang terbesar diantara jenis lainnya yaitu sebesar $92,56 \mathrm{~cm}$ dengan laju pertumbuhan $(k)$ sebesar 0,10/tahun.

Sementara itu, ikan kerapu sunu jenis Plectropomus areolatus memiliki panjang asimptotik $(L \infty)$ yang terendah dibandingkan jenis lainnya yaitu sebesar $62,16 \mathrm{~cm}$ dan laju pertumbuhan $(k)$ sebesar $0,10 /$ tahun.

\section{Mortalitas dan Laju Pemanfaatan}

Laju kematian yang diduga adalah laju kematian total $(Z)$, laju kematian alami (M), dan laju kematian penangkapan (F). Hasil analisis regresi kurva konversi hasil tangkapan ikan kerapu sunu yang dilinearkan berbasis data panjang disajikan pada Tabel 3.

Nilai Mortalitas alami (M) ikan kerapu sunu di Perairan Karimunjawa berkisar antara 0,13-0,18 per tahun. Menurut Pauly (1984) dan Catalano \& Allen (2010) faktor yang mempengaruhi nilai $\mathrm{M}$ adalah suhu rata-rata perairan dan laju pertumbuhan $(k)$. Nilai $M$ untuk ikan kerapu sunu $P$. leopardus dibeberapa perairan seperti Peraian Kloaka (Landu 2013) sebesar 0,6/tahun dan di Perairan Lasongko (Prasetya 2010) sebesar 0,49/tahun, lebih besar dibandingkan di Perairan Karimunjawa. Nilai M kerapu sunu bintang timur di Karimunjawa tergolong kecil menurut 
klasifikasi dari Beverton \& Holt (1959) yang menyatakan nilai $M$ yang tergolong tinggi berkisar antara 1,5-2,5 hal ini sesuai dengan penyataan Ferreira \& Russ (1994) dan Heemstra \& Randall (2005).

\section{Rata-rata Panjang Ikan Pertama Kali Tertangkap ( $L C$ ), Nilai Dugaan Panjang Ikan Pertama Kali Matang Gonad (Lm), dan Nilai Dugaan Panjang Optimal Ikan}

Beverton dan Holt (1957) in Saparre dan Venema (1999) menyatakan bahwa ukuran pertama kali tertangkap $(L C)$ adalah ukuran dimana 50\% ikan dipertahankan dan 50\% ikan dilepaskan oleh suatu alat tangkap ikan. Ikan dengan ukuran dibawah $L c$ akan lolos dari kegiatan penangkapan dan dapat berkembang hingga ukurannya lebih besar. Rata-rata panjang ikan pertama kali tertangkap untuk kerapu sunu di Perairan Karimunjawa disajikan pada Tabel 4.

Menurut Froese dan Binohlan (2000) terdapat hubungan empiris yang dapat menduga nilai panjang pertama kali matang gonad $(L m)$ dari $L_{\infty}$ dan panjang optimal (Lopt) dari persamaan grafik pertumbuhan von Bertalanffy dan mortalitas alami $(M)$. Hubungan empiris tersebut digunakan ketika data yang dibutuhkan untuk menduga $L m$ seperti jenis kelamin, suhu, dan fekunditas tidak tersedia. Estimasi Lopt membutuhkan data $k$ dari von Bertalanffy growth function dan kematian alami (M). Grafik frekuensi panjang ikan kerapu sunu masingmasing spesies disajikan pada Gambar 1.

Tabel 1 Jumlah contoh (n) setiap jenis ikan kerapu sunudari genus Plectropomus sp.

\begin{tabular}{|c|c|c|c|c|}
\hline Spesies & Alat tangkap & $\begin{array}{c}n \\
\text { (individu) }\end{array}$ & $\begin{array}{l}\text { Panjang rata- } \\
\text { rata }(\mathrm{cm})\end{array}$ & SD \\
\hline $\begin{array}{l}\text { Plectropomus areolatu } \\
\text { (sunu hitam) }\end{array}$ & $\begin{array}{l}\text { Pancing ulur, panah, bubu, } \\
\text { pancing tonda }\end{array}$ & 422 & 38,89 & 18,62 \\
\hline $\begin{array}{l}\text { Plectropomus leopardus (sunu } \\
\text { bintang timur) }\end{array}$ & $\begin{array}{l}\text { Pancing ulur, muroami, } \\
\text { panah, bubu, pancing } \\
\text { tonda }\end{array}$ & 410 & 39,64 & 10,18 \\
\hline $\begin{array}{l}\text { Plectropomus maculatus (sunu } \\
\text { kuning) }\end{array}$ & $\begin{array}{l}\text { Pancing ulur, muroami, } \\
\text { panah, bubu, pancing } \\
\text { tonda }\end{array}$ & 928 & 43,71 & 11,93 \\
\hline $\begin{array}{l}\text { Plectropomus oligacanthus (sunu } \\
\text { macan) }\end{array}$ & $\begin{array}{l}\text { Pancing ulur, muroami, } \\
\text { panah, bubu, pancing } \\
\text { tonda }\end{array}$ & 1369 & 39,69 & 8,72 \\
\hline
\end{tabular}

Tabel 2 Parameter pertumbuhan $\left(L \infty, k\right.$, dan $\left.t_{0}\right)$ ikan kerapu sunu

\begin{tabular}{lcccc}
\hline \multirow{2}{*}{ Spesies } & \multicolumn{4}{c}{ Parameter pertumbuhan } \\
\cline { 2 - 5 } & $\boldsymbol{L}(\mathbf{c m})$ & $\boldsymbol{k}$ (tahun-1) & $\boldsymbol{t}_{\text {o }}$ (tahun) & $\begin{array}{c}\text { Lifespan } \\
\text { (tahun) }\end{array}$ \\
\hline Plectropomus areolatus (sunu hitam) & 62,16 & 0,10 & $-1,37$ & 27.73 \\
Plectropomus leopardus (sunu bintang timur) & 70,00 & 0,10 & $-1,31$ & 27,22 \\
Plectropomus maculatus (sunu kuning) & 92,56 & 0,10 & $-1,21$ & 27,24 \\
Plectropomus oligacanthus (sunu macan) & 67,93 & 0,13 & $-1,05$ & 21,93 \\
\hline
\end{tabular}

Tabel 3 Laju mortalitas dan tingkat pemanfaatan/ laju eksploitasi (M, F, Z, dan E) ikan kerapu sunu (Plectropomus sp.)

\begin{tabular}{lcccc}
\hline \multirow{2}{*}{ Spesies } & \multicolumn{4}{c}{ Parameter mortalitas } \\
\cline { 2 - 5 } & $\boldsymbol{M}$ (tahun-1) & $\boldsymbol{F}$ (tahun-1) & $\boldsymbol{Z}$ (tahun-1) & $\boldsymbol{E}$ \\
\hline Plectropomus areolatus (sunu hitam) & 0,13 & 0,14 & 0,28 & 0,50 \\
Plectropomus leopardus (sunu bintang timur) & 0,13 & 0,11 & 0,25 & 0,45 \\
Plectropomus maculatus (sunu kuning) & 0,14 & 0,23 & 0,37 & 0,61 \\
Plectropomus oligacanthus (sunu macan) & 0,18 & 0,19 & 0,37 & 0,51 \\
\hline
\end{tabular}


Tabel 4 Rata-rata panjang ikan pertama kali tertangkap $(L C)$

\begin{tabular}{lccc}
\hline Spesies & $\boldsymbol{L}_{\mathbf{5 0}}$ atau $\boldsymbol{L c} \mathbf{( c m )}$ & $\mathbf{L m}$ & Lopt \\
\hline Plectropomus areolatus (sunu hitam) & 30,37 & 34,05 & 39,33 \\
Plectropomus leopardus (sunu bintang timur) & 28,58 & 37,89 & 44,52 \\
Plectropomus maculatus (sunu kuning) & 33,50 & 48.69 & 59,56 \\
Plectropomus oligacanthus (sunu macan) & 33,50 & 36,88 & 43,15 \\
\hline
\end{tabular}

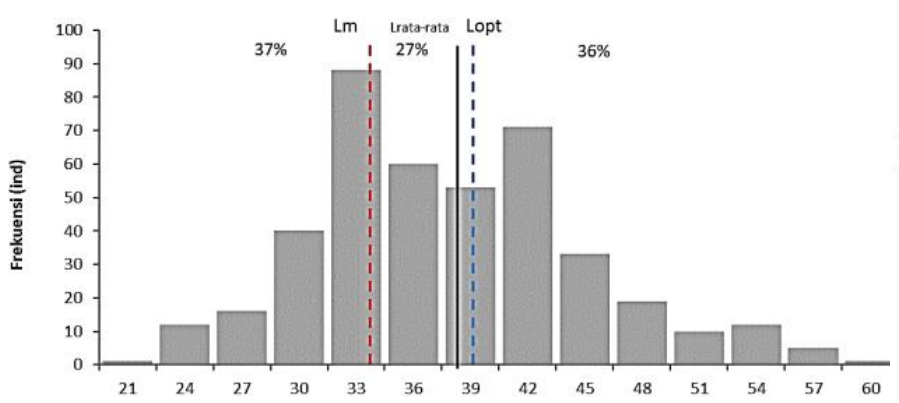

Panjang total (cm)

(a)

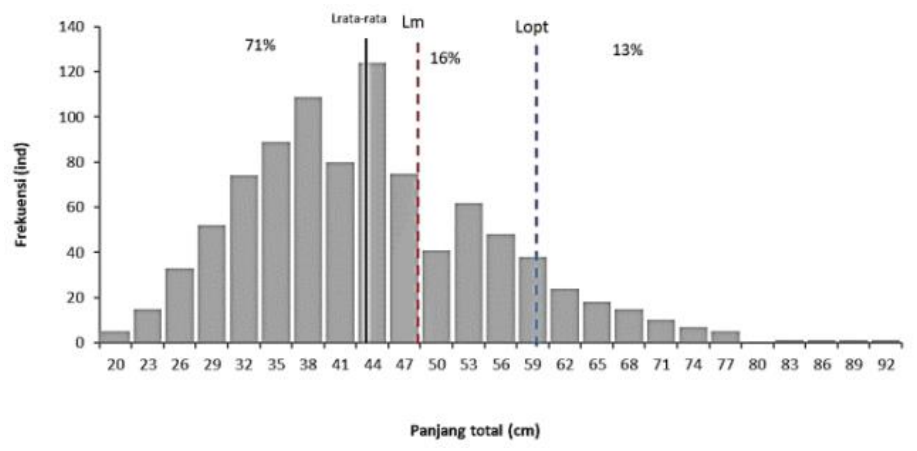

(c)

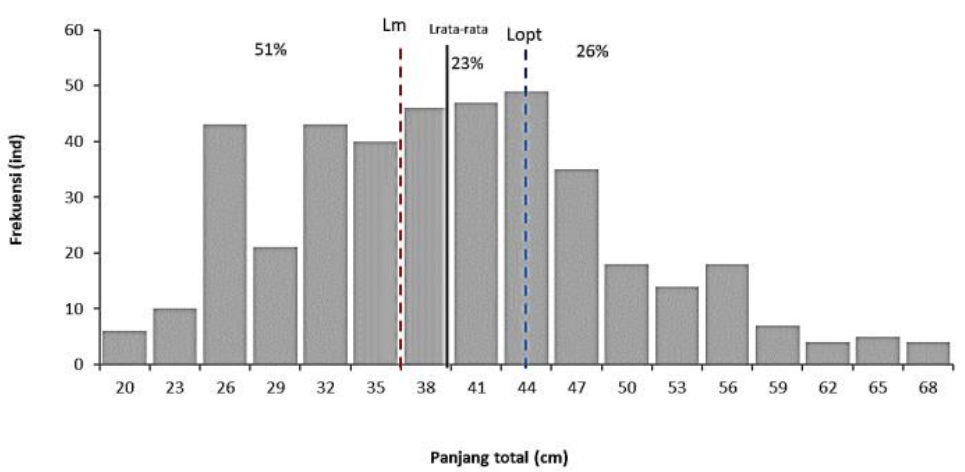

(b)

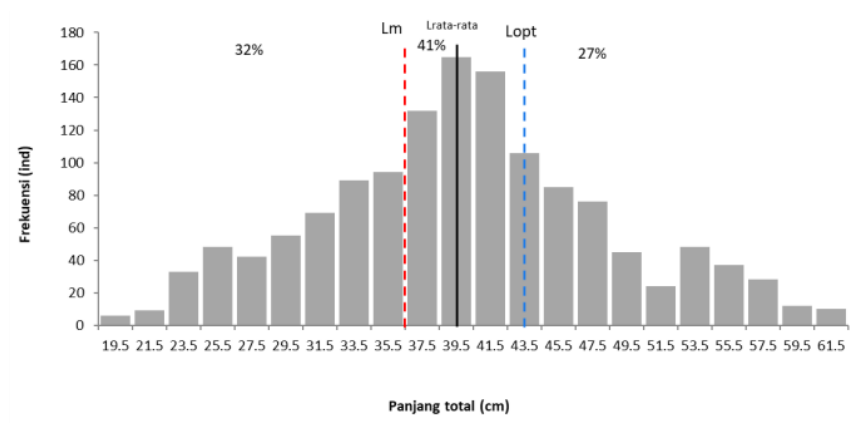

(d)

Gambar 1 Sebaran frekuensi panjang ikan kerapu sunu jenis (a) Plectropomus areolatus, (b) Plectropomus leopardus, (c) Plectropomus maculatus, dan (d) Plectropomus oligacanthus

\section{Pola Rekrutmen}

Pola rekrutmen ikan kerapu sunu disajikan pada Gambar 2. Keempat jenis ikan kerapu sunu mengalami dua kali puncak rekrutmen dalam satu tahun. Modus pada grafik rekrutmen menunjukkan adanya penambahan individu baru pada populasi ikan. Penambahan tersebut dapat berupa individu hasil reproduksi ataupun penambahan akibat migrasi dari tempat lain.

\section{Spawning Potential Ratio (SPR)}

Spawning potential ratio (SPR) atau rasio potensi pemijahan adalah jumlah telur yang dapat dihasilkan, rata-rata dalam suatu sedia- an/stok induk ikan dibagi dengan jumlah yang dapat dihasilkan oleh rata-rata dalam sediaan stok induk yang tidak tertangkap (Blackhart et al. 2006). Hasil analisis SPR untuk ikan kerapu sunu disajikan Gambar 3, Gambar 4, Gambar 5, Gambar 6 dan pada Tabel 5 untuk nilai SPR pada tahun terakhir.

\section{PEMBAHASAN}

Ikan kerapu sunu di perairan Karimunjawa yang teridentifikasi selama pengambilan ada ada 5 jenis yaitu Plectropomus areolatus, $P$. laevis, $P$. leopardus, $P$. maculatus, dan $P$. oligacanthus (Yulianto et al. 2015). Berdasar- 


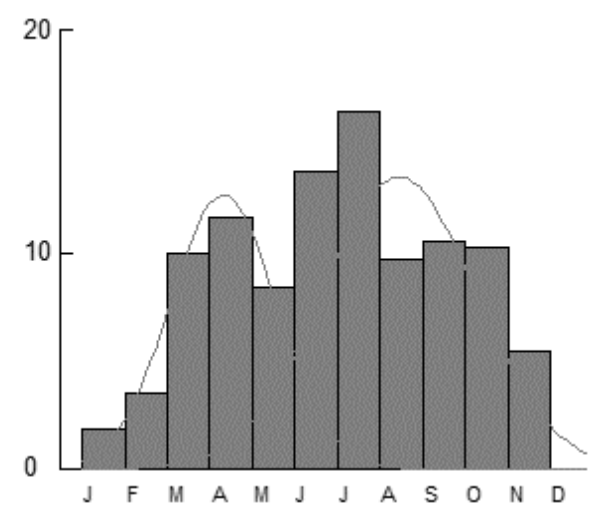

(a)

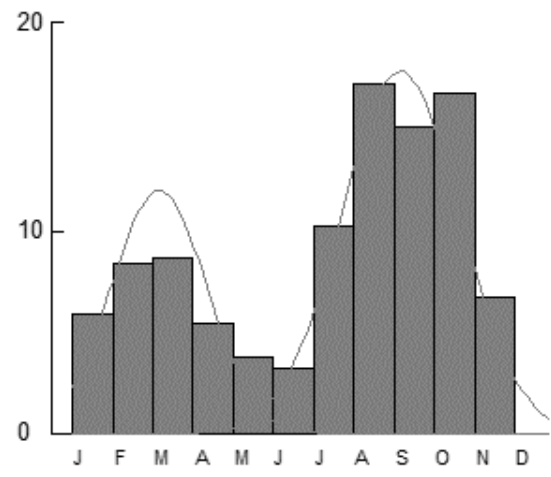

(c)

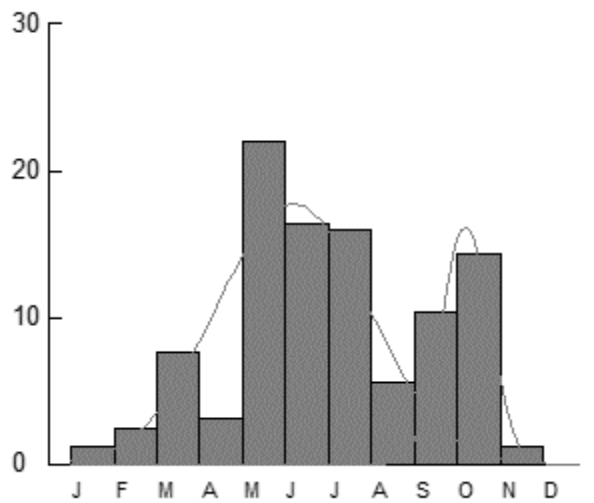

(b)

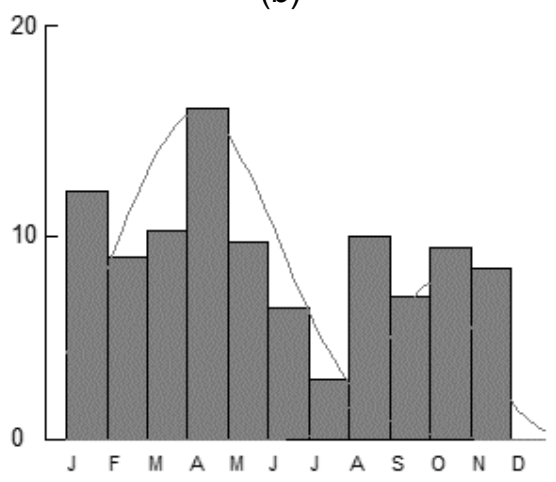

(d)

Gambar 2 Pola rekrutmen ikan kerapu sunu (a) Plectropomus areolatus, (b) Plectropomus leopardus, (c) Plectropomus maculatus, dan (d) Plectropomus oligacanthus

Tabel 5 Puncak rekrutmen ikan kerapu sunu

\begin{tabular}{lll}
\hline Spesies & Pola rekrutmen & Puncak rekrutmen \\
\hline Plectropomus areolatus (sunu hitam) & Partial spawner & April dan Juni \\
Plectropomus leopardus (sunu bintang timur) & Partial spawner & Mei dan Oktober \\
Plectropomus maculatus (sunu kuning) & Partial spawner & April dan Agustus \\
Plectropomus oligacanthus (sunu macan) & Partial spawner & April dan Oktober \\
\hline
\end{tabular}
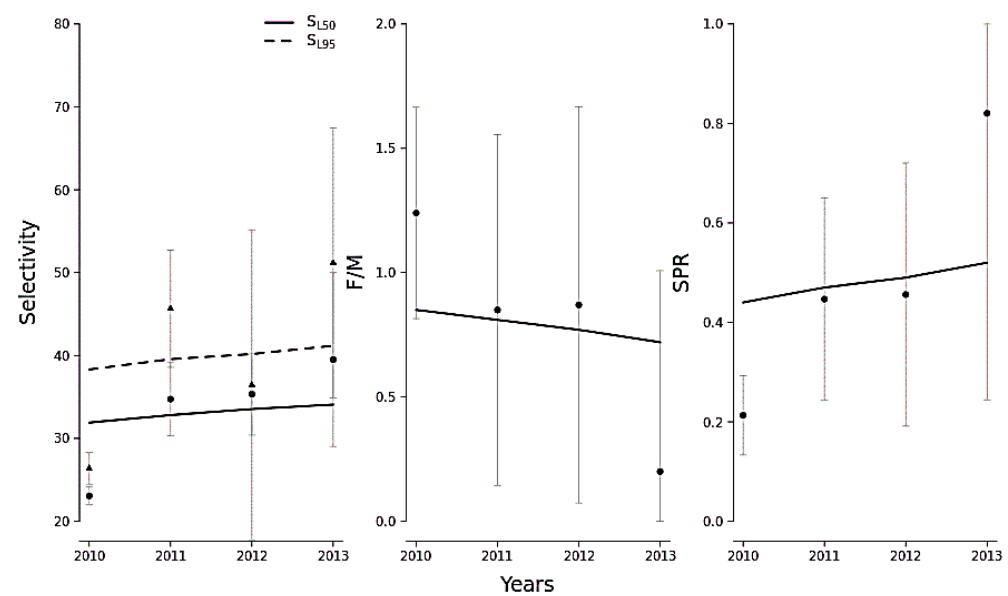

Gambar 3 Kurva perubahan selektivitas, F/M, dan SPR ikan kerapu sunu $P$. areolatus tahun 20102015 


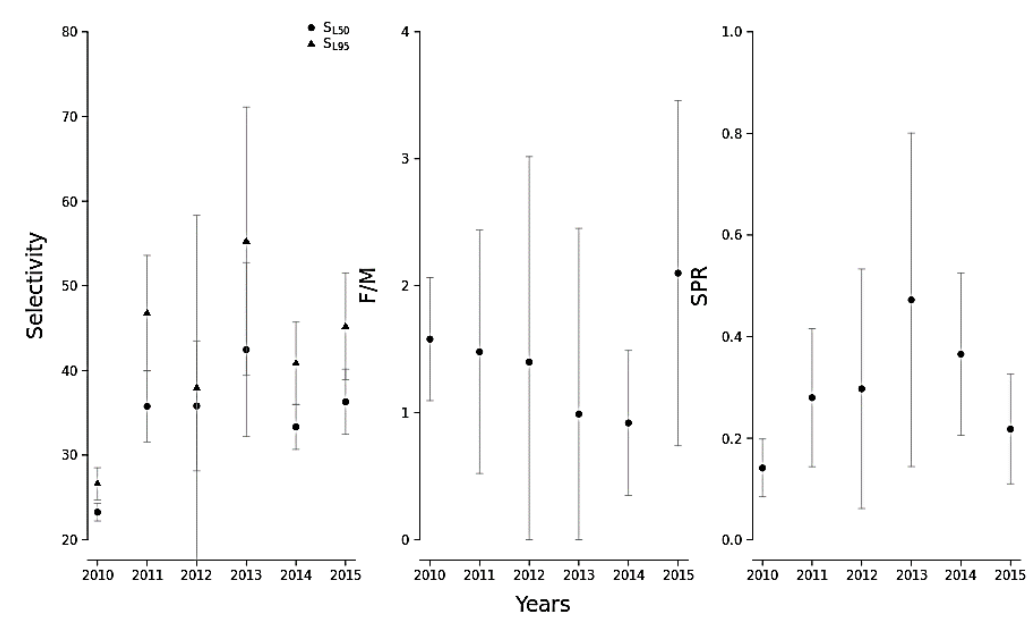

Gambar 4 Kurva perubahan selektivitas, F/M, dan SPR ikan kerapu sunu $P$. leopardus tahun 20102015

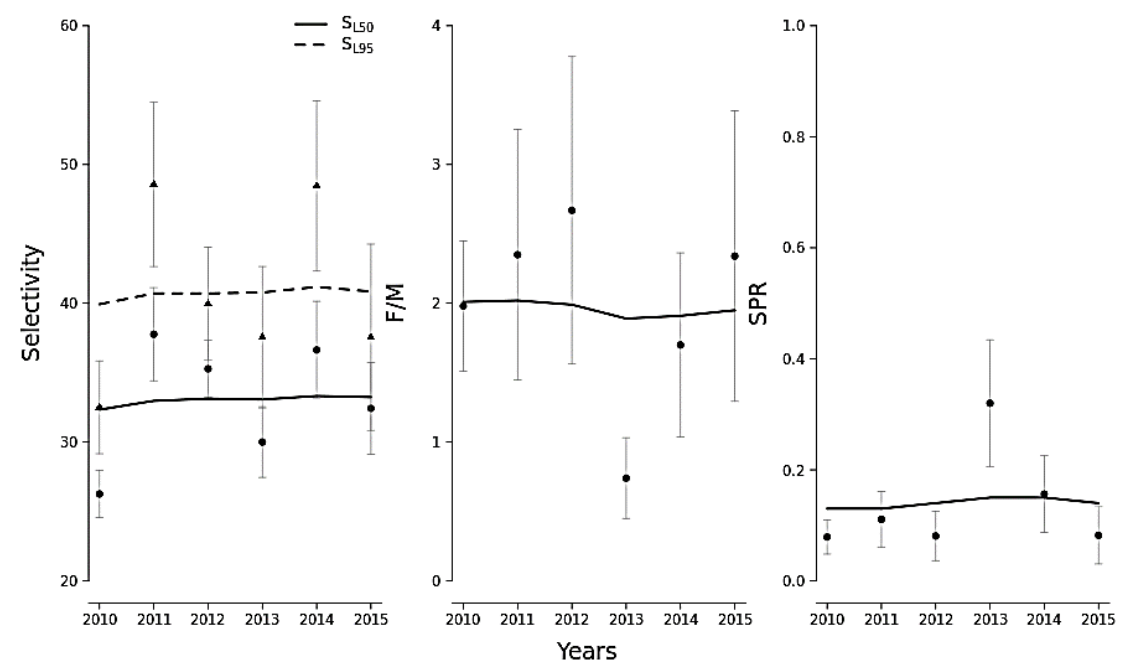

Gambar 5 Kurva perubahan selektivitas, F/M, dan SPR ikan kerapu sunu P. maculatus tahun 2010-2015
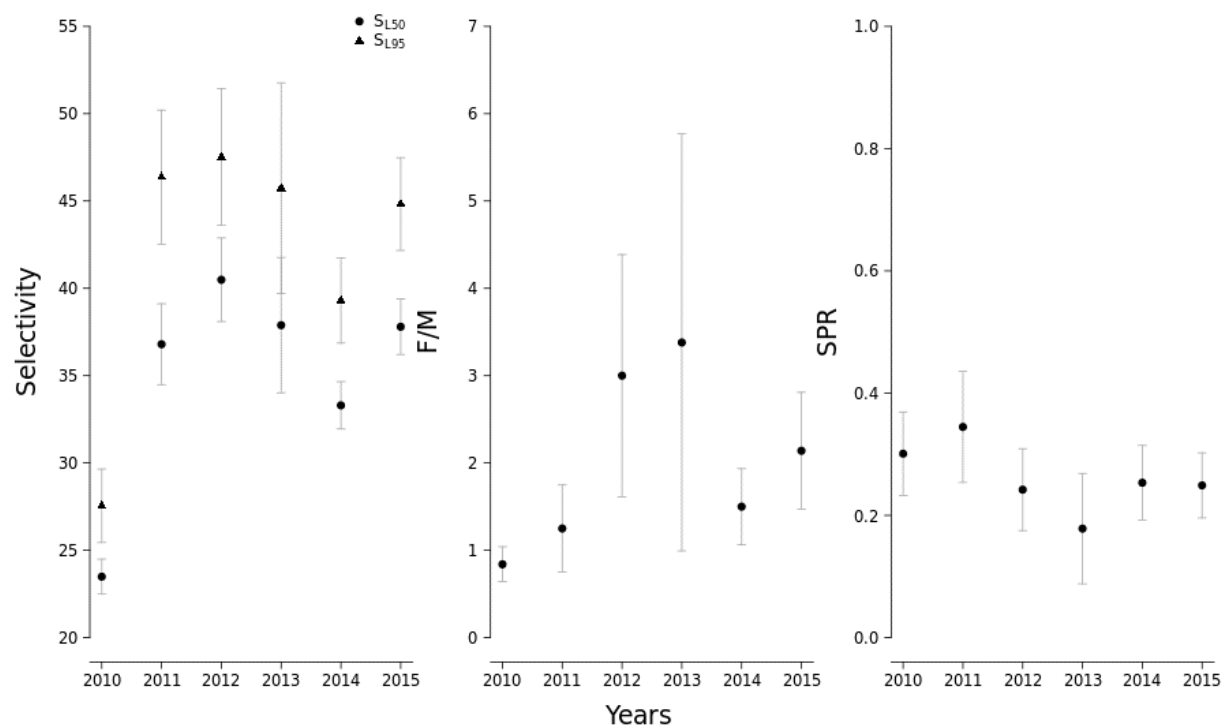

Gambar 6 Kurva perubahan selektivitas, F/M, dan SPR ikan kerapu sunuP. oligacanthus tahun 2010-2015 
Tabel 6 Spawning potential ratio (SPR) ikan kerapu sunu

\begin{tabular}{lcc}
\hline \multicolumn{1}{c}{ Spesies } & SPR & $\begin{array}{c}\text { Status stok (Aultet al. 2008; } \\
\text { Badrudin 2015) }\end{array}$ \\
\hline Plectropomus areolatus (sunu hitam) & 0,52 & $>30 \%$ \\
Plectropomus leopardus (sunu bintang timur) & 0,22 & $<30 \%$ \\
Plectropomus maculatus (sunu kuning) & 0,14 & $<30 \%$ \\
Plectropomus oligacanthus (sunu macan) & 0,25 & $<30 \%$ \\
\hline
\end{tabular}

kan ketersediaan data 4 diantaranya dilakukan analisis parameter pertumbuhan dan status stok perikanan. Parameter pertumbuhan yang dianalisis adalah panjang asimptotik dan koefisisen pertumbuhan. Berdasarkan parameter pertumbuhan panjang asimptotik ikan kerapu sunu macan dan sunu hitam relatif lebih kecil dibandingkan jenis kerapu sunu lainnya di Perairan Karimunjawa yaitu $67,93 \mathrm{~cm}$ dan $62,16 \mathrm{~cm}$. Hal ini sejalan dengan hasil penelitian Sitepu (2007) bahwa ikan kerapu sunu hitam ( $P$. areolatus) tergolong spesies berukuran kecil dengan ukuran $<70 \mathrm{~cm}$. Perbedaan ukuran ikan di perairan yang berbeda diduga disebabkan oleh perbedaan lingkungan perairan misalnya habitat dan ketersediaan makanan (Sudirman dan Karim 2008).

Koefisien pertumbuhan $(k)$ ikan kerapu sunu di Karimunjawa berkisar antara 0,10-0,13 relatif sama dengan $k$ di Perairan Coron dan Guiuan, Philipina yang mencapai 0,13/tahun (Mamauag et al. 2000). Hal ini mengindikasikan bahwa ikan kerapu sunu dari jenis Plectropomus sp. memiliki pertumbuhan yang cukup lambat dibandingkan kerapu dari jenis lainnya. Kecepatan tumbuh ikan dapat mengindikasikan kondisi perairan dan kelimpahan makanan (Hernandez \& Seijo 2003). Menurut Campbell et al. (2013) kondisi Perairan Karimunjawa secara umum masih tergolong baik dan sangat baik secara ekologi.

Nilai $k$ dan to yang didapatkan juga dipergunakan untuk mengestimasi umur harapan hidup (lifespan) ikan kerapu sunu. Menurut Pauly (1984) hubungan antara pendugaan umur dengan kecepatan pertumbuhan sangat erat dan memainkan peranan penting dalam dinamika populasi ikan. Lifespan merupakan umur ikan pada saat panjangnya mencapai 95\% dari panjang asimptotik $\left(L^{\infty}\right)$ (Taylor 1958 dalam Pauly 1984). Penentuan umur adalah salah satu komponen penting dalam kajian stok sumber daya terutama ikan karang (Sadovy et al. 1992; Manickchand-Heileman dan Philip 2000). Berdasarkan Tabel 2 kisaran umur harapan ikan kerapu sunu berkisar antara 21,9327,73 tahun. Hasil penelitian Bullock et al. (1992) dalam Brusher \& Schull (2009) menun- jukkan bahwa ikan kerapu sunu memiliki nilai $k$ yang relatif lebih kecil di perairan subtropis. Selain itu, ikan kerapu sunu juga memiliki karakteristik pertumbuhan yang lambat, lifespan yang panjang, dan laju kematian alami yang lambat (Ferreira \& Russ 1994; Heemstra \&Randall 2005). Hal ini menyebabkan ikan kerapu sunu memiliki nilai mortalitas (kematian) dan kerentanan yang tinggi terhadap tekanan penangkapan sehingga mudah mengarah pada kondisi overfished dan overfishing.

Mortalitas pada ikan dibedakan menjadi mortalitas alami (M) atau kematian akibat umur, kompetisi, predasi, dan penyakit dan mortalitas penangkapan $(F)$ atau kematian akibat kegiatan penangkapan. Mortalitas penangkapan (F) merupakan fungsi dari upaya penangkapan. Nilai $F$ untuk jenis kerapu sunu hitam dan sunu kuning lebih besar dibandingkan mortalitas alaminya, yang artinya untuk kedua jenis kerapu sunu ini kematian didominasi oleh kegiatan penangkapan. Nilai mortalitas alami (M) untuk ikan kerapu sunu bintang timur dan sunu macan lebih tinggi dibandingkan mortalitas penangkapannya $(F)$, yang berarti sebaliknya, ikan kerapu jenis tersebut lebih banyak mati secara alami seperti akibat predasi dan kondisi lingkungan. Nilai F yang tinggi berdampak pada nilai eksploitasi atau laju pemanfaatan ikan yang tinggi, sehingga laju eksploitasi melebihi eksploitasi optimumnya. Eksploitasi optimal menurut Pauly (1984) dan King (1995) terjadi ketika mortalitas penangkapan sebanding dengan mortalitas alaminya. Menurut Burton (2002) laju eksploitasi yang tinggi berpotensi merusak kestabilan stok dalam suatu perairan.

Laju eksploitasi disarankan sebagai indikator untuk mengukur tekanan penangkapan dengan titik acuan target (target reference point) sebesar 0,5 (Pauly 1984; Rochet \& Trenkel 2003). Berdasarkan Tabel 3 ikan sunu kuning jenis Plectropomus areolatus dan $P$. leopardus laju eksploitasinya sebesar 0,50 dan 0,45 berada di bawah eksploitasi optimumnya. Sedangkan Plectropomus maculatus dan Plectropomus oligacanthu ssebesar 0,61 dan 0,51 yang berarti telah melebihi batas optimumnya dan mengarah pada penangkapan berlebih. 
Penangkapan ikan yang berlebihan akan menurunkan ukuran dan umur ikan pada populasi tersebut (Sanchez 2000). Ciri-ciri ikan yang mengalami eksploitasi tinggi adalah perubahan komposisi ukuran ikan menjadi lebih kecil sehingga secara signifikan akan berpengaruh terhadap hasil produksi (Effendi 2002; Hurtado et al. 2005; Nelson et al. 2007). Berdasarkan hasil pendugaan rata-rata panjang ikan kerapu sunu tahun 2010-2015, ikan kerapu jenis $P$. areolatus mengalami penurunan rata-rata ukuran panjang mulai tahun 2012-2015 namun tidak signifikan. Sedangkan jenis $P$. oligacanthus rata-rata panjang ikan menurun sampai tahun 2013 dan kembali meningkat sampai 2015, jenis $P$.leopardus dan $P$. maculatus mempunyai pola yang sama yaitu menurun mulai tahun 2013-2015.

Berdasarkan hubungan empiris antar ukuran panjang pada Gambar 1 terlihat bahwa kerapu sunu di Karimunjawa tertangkap sebelum mengalami matang gonad ( $L c<L m)$. Hal ini menunjukan bahwa ikan-ikan tersebut sebanyak $50 \%$ tertangkap pada ukuran sebelum matang gonad dan berukuran kecil. Kondisi Lc $<$ Lm menunjukkan peluang terjadinya overfishing relatif tinggi. Kondisi overfishing yang mungkin terjadi adalah growth dan recruitment overfishing. Growth overfishing terjadi apabila hasil tangkapan didominasi oleh ikan-ikan kecil atau ikan muda pada ukuran pertumbuhan, sedangkan recruitment overfishing terjadi apabila kegiatan eksploitasi lebih banyak menangkap ikan yang siap memijah (spawning stock) atau ikan dewasa matang gonad (Widodo dan Suadi 2006). Dengan mempertimbangkan kemungkinan terjadinya growth dan recruitment overfishing, maka dalam pengelolaan diduga panjang optimal (Lopt) sebagai acuan ukuran yang sesuai untuk penangkapan. Lopt untuk ikan kerapu sunu jenis $P$. areolatus sebesar 39,33 cm, $P$. leopardus sebesar 44,52 $\mathrm{cm}, P$. maculatus sebesar $59,56 \mathrm{~cm}$ dan untuk $P$. oligacanthus sebesar $43,15 \mathrm{~cm}$.

Berdasarkan pendugaan panjang pertama kali dewasa ikan kerapu sunu jenis $P$. areolatus pada usia 3,09 tahun, $P$. leopardus mencapai dewasa pada usia 4 tahun, $P$. maculatus pada usia 4,17 tahun, dan $P$. Oligacanthus pada usia 3 tahun. Usia dewasa ikan kerapu sunu kuning di Perairan Karimunjawa relatif lebih tinggi dibandingkan hasil penelitian Ferreira (1993) yang menyatakan ikan kerapu sunu kuning ( $P$. maculatus) mencapai dewasa pada usia 2-3 tahun dan menurut Elevati \& Aditya (2001) ikan kerapu sunu (Plectropomus sp.) yang dibesarkan di keramba mencapai dewasa pada usia 3 tahun. Setelah mengalami matang gonad pertama kali, maka ikan kerapu akan mengalami perubahan kelamin.

Ikan kerapu merupakan ikan yang bersifat hermaprhodite protogynous, yaitu proses deferensiasi gonadnya berjalan dari fase betina ke fase jantan setelah mencapai ukuran tertentu atau setidaknya telah mengalami satu kali memijah (Effendie 2002; Widodo 2006). Menurut Elevaty \& Aditya (2001) perubahan kelamin terjadi pada ukuran $42-62 \mathrm{~cm}$, sedangkan di Laut Merah (DesRoisers 2011) perubahan kelamin kerapu sunu hitam (Plectropomus spp.) terjadi pada ukuran 40,3 cm dengan usia 2,84 tahun. Berdasarkan analisis panjang pertama kali ikan tertangkap, ukuran ikan kerapu sunu pertama kali tertangkap berkisar antara 37,80$43,07 \mathrm{~cm}$, sehingga ikan yang tertangkap di Perairan Karimunjawa dominan pada fase kelamin betinanya. Kondisi penangkapan betina yang dominan menyebabkan proporsi betina menurun dalam populasi dan mengganggu keseimbangan reproduksi karena keterbatasan jumlah telur (Grandcourt et al. 2005). Untuk menjaga keseimbangan reproduksi penting mengetahui informasi tentang puncak rekrutmen atau pemijahan ikan sebagai dasar dalam melakukan pengelolaan perikanan.

Pola rekrutmen ikan kerapu sunu di Karimunjawa adalah partial spawner. Menurut Pauly (1982) puncak rekrutmen yang bersifat parsial umum terjadi pada spesies ikan tropis. Puncak rekrutmen Plectropomus areolatus diduga terjadi pada bulan April dan Juni, $P$. leopardus diduga terjadi pada bulan Mei dan Oktober, $P$. maculatus pertama terjadi pada bulan April dan puncak kedua terjadi pada bulan Agustus. Puncak rekrutmen Plectropomus oligacanthus yang pertama terjadi pada bulan April dan puncak kedua terjadi pada bulan Oktober. Puncak pemijahan ikan kerapu sunu di Perairan Kolaka Sulawesi Tenggara bersifat total spawner dan diduga terjadi pada bulan Agustus/ September (Landu 2013). Puncak rekrutmen suatu spesies ikan dapat dijadikan sebagai pertimbangan penentuan waktu pemijahan. Pada saat puncak pemijahan ikan kerapu akan melakukan pemijahan masal dengan densitas dan jumlah secara signifikan lebih tinggi dibandingkan dengan densitas dan jumlah ikan dilokasi agregasi tersebut pada saat tidak dalam masa reproduksi (Utojo et al. 1999). Menurut Sadovy (2005) lokasi dan waktu agregasi selalu tetap dalam jangka waktu yang lama sehingga kumpulan ini menjadi target penangkapan oleh nelayan. Eksploitasi berlebihan pada waktu dan lokasi pemijahan akan berimplikasi terhadap ekologi reproduksi.

Pendugaan status pemanfaatan sumber daya ikan juga dapat diduga dengan rasio dari spawning stock biomass. Rasio potensi pemi- 
jahan atau Spawning Potential Ratio (SPR) menggambarkan kapasitas reproduksi dari suatu sumber daya ikan.

Populasi ikan yang sehat memiliki nilai SPR yang tinggi, karena dewasa matang tesedia cukup untuk melakukan reproduksi. Pendugaan nilai SPR dipengaruhi oleh selektivitas dan kurva pemijahan serta rasio F/M dari life history masing-masing ikan. Gambar 3 menunjukkan bahwa panjang ikan pertama kali tertangkap (SL50 atau LC) mengalami peningkatan dengan $\mathrm{F} / \mathrm{M}$ yang mengalami penurunan mulai tahun 2010 hingga 2015. Hal ini menunjukkan bahwa tekanan penangkapan akibat kegiatan penangkapan mengalami penurunan sehingga nilai SPR tahun 2015 mengalami peningkatan yaitu sebesar 0,52 atau $52 \%$. Kondisi ini menunjukkan potensi pemijahan ikan kerapu sunu $P$. areolatus lebih besar dari SPR standar menurut Ault et al. (2008) yaitu 30\%. Artinya agregasi pemijahan ikan tersebut dalam kondisi baik. Berdasarkan kondisi penangkapan ikan kerapu sunu hitam tertangkap pada kondisi immature sebesar $37 \%$ dan proporsi ikan yang tertangkap setelah mengalami matang gonad sebesar $60-70 \%$. Kondisi ini berdampak positif terhadap agregasi pemijahan ikan sunu hitam.

Gambar 4 menunjukan bahwa selektivitas atau panjang ikan pertama kali tertangkap (LC atau L50) ikan kerapu sunu bintang timur mengalami peningkatan mulai tahun 2010 sampai 2013 dan menurun dari tahun 2014 sampai 2015 dengan rasio $F / M$ yang menurun hingga tahun 2014 dan meningkat tahun 2015. Kondisi ini mempengaruhi rasio potensi pemijahan ikan kerapu sunu bintang timur yang mengalami penurunan pada tahun 2015. Gambar 5 menunjukkan nilai selektivitas ikan kerapu sunu kuning mengalami penurunan mulai tahun 2014 sampai 2015 dengan rasio F/M yang meningkat. Kondisi ini mempengaruhi nilai SPR ikan yang mengalami penurunan mulai tahun 2013 hingga 2015. Gambar 6 menunjukan bahwa selektivitas penangkapan ikan kerapu sunu macan mengalami peningkatan tahun 2014 sampai 2015 dengan rasio F/M yang mengalami penurunan, artinya penangkapan akibat kegiatan penangkapan (F) mengalami penuruan. Hal ini berdampak positif terhadap peningkatan nilai SPR ikan kerapu sunu macan yang cenderung meningkat mulai tahun 2013.

Nilai SPR ikan kerapu sunu bintang timur, sunu kuning, dan sunu macan sebesar $0,22,0,14$, dan 0,25 dan berada di bawah SPR standar (Ault et al. 2008) artinya penangkapan yang terjadi saat ini berada pada tingkat yang tidak berkelanjutan (overfished). Berdasarkan ukuran ikan tertangkap ikan sunu bintang timur tertangkap pada kondisi immature sebesar $51 \%$, sunu kuning sebesar $71 \%$, dan sunu macan sebesar $32 \%$.

\section{Intervensi Pengelolaan}

Berdasarkan parameter-parameter populasi ikan kerapu sunu, maka kegiatan pengelolaan kerapu sunu yang dapat dilakukan di Kepulauan Karimunjawa adalah mengatur dengan ketat kegiatan penangkapan untuk ikan kerapu sunu kuning, mengurangi tekanan perikanan untuk ikan kerapu sunu bintang timur dan sunu macan, dan mendorong tingkat pemanfaatan ikan kerapu sunu hitam.

Kerapu sunu kuning diduga telah mengalami eksploitasi berlebih (overfished) dengan nilai SPR 0,14, ukuran pertama kali tertangkap jauh dibawah dugaan ukuran dewasa, dan tingkat kematian akibat penangkapan lebih tinggi dibandingkan tingkat kematian alamiahnya (tingkat eksploitasi diatas 0,5). Salah satu langkah pengaturan dengan ketat terhadap sunu kuning adalah penutupan kegiatan penangkapan terhadap ikan kerapu sunu kuning beberapa saat yang diharapkan dapat memulihkan stok ikan kerapu sunu kuning. Berdasarkan parameter populasi, penutupan kegiatan penangkapan dapat dilakukan paling tidak sekitar 6 bulan, dimana ikan sunu kuning pada saat penutupan dapat melakukan rekruitmen sebanyak satu kali tanpa adanya kegiatan pemanfaatan. Pengaturan lainnya yang dapat dilakukan terhadap sunu kuning adalah pengaturan waktu penangkapan.

Kerapu sunu bintang timur dan sunu macan, berdasarkan SPR berada pada kondisi eksploitasi berlebihan namun dengan nilai SPR yang lebih tinggi dibandingkan kerapu sunu kuning, sehingga perlu pengaturan untuk mengurangi tekanan perikanan terhadap spesies tersebut. Pengaturan terhadap sunu bintang timurdan sunu macan dapat dilakukan dengan pambatasan ukuran minimal yang boleh ditangkap dan pembatasan waktu-waktu tertentu untuk melakukan penangkapan. Pembatasan waktu penangkapan sunu bintan timur dapat dilakukan pada saat bulan baru khususnya pada puncak rekruitmen di bulan April dan Agustus dan untuk sunu macan dapat dilakukan secara khusus pada bulan April dan Juni.

Pembatasan waktu penangkapan dan perubahan ukuran tangkapan berdampak positif terhadap biomassa ikan kerapu (Yulianto et al. 2015, Chiappone et al.2000). Tingkat pemanfaatan sunu hitam masih dibawah 0,5 dengan nilai SPR 0,52, sehingga ikan kerapu sunu macan masih bisa ditingkatkan lagi pemanfaatannya. Tentu saja dengan nilai ukuran per- 
tama kali tertangkap yang sama. Hal ini juga merupakan solusi atau alternatif bagi nelayan yang terdampak, jika penutupan pemanfaatan ikan sunu kuning diberlakukan.

\section{KESIMPULAN}

Ikan kerapu sunu (Plectropomus sp.) tergolong dalam spesies yang pertumbuhannya lambat dan berumur panjang dengan lifespan berkisar 21,93-27,73 tahun. Laju kematian akibat penangkapan berkontribusi lebih besar daripada kematian alaminya untuk jenis P.leopardus, $P$. maculatus, dan $P$. oligacanthus. Kondisi stok ikan kerapu sunu jenis $P$. leopardus, $P$. maculatus, dan $P$. oligacanthus diindikasikan mengalami kondisi tangkap lebih dengan E>0,5 dan SPR sebesar 0,14, 0,22, dan 0,25. Kerapu sunu jenis $P$. areolatus memiliki $E$ sebesar 0,45 dan SPR 0,52, artinya kerapu jenis ini memiliki tingkat eksploitasi yang rendah dan potensi pemijahan yang tinggi dibandingkan jenis kerapu sunu lainnya di Perairan Karimunjawa. Opsi kegiatan pengelolaan kerapu sunu yang dapat dilakukan di Kepulauan Karimunjawa adalah menutup kegiatan penangkapan untuk ikan kerapu sunu kuning, mengurangi tekanan perikanan untuk ikan kerapu sunu bintang timur dan sunu macan, dan mendorong tingkat pemanfaatan ikan kerapu sunu hitam.

\section{SARAN}

Berdasarkan hasil penelitian kajian biologi perikanan kerapu sunu ini, didapatkan opsi pengelolaan yang mungkin dilakukan di Karimunjawa untuk menjaga penangkapan pada tingkat yang berkelanjutan. Pengelolaan yang dapat dilakukan diantaranya adalah melakukan penutupan penangkapan sementara bagi ikan overfished dengan rasio potensi pemijahan yang rendah, mengurangi tekanan penangkapan dengan pengaturan upaya penangkapan dan ukuran penangkapan.

\section{UCAPAN TERIMA KASIH}

Penulis mengucapkan terima kasih kepada MPA Fund atas dana dalam penelitian ini, Balai Taman Nasional Karimunjawa, Dinas Kelautan dan Perikanan (DKP) Provinsi Jawa Tengah, DKP Kabupaten Jepara, dan Pemerintah Kecamatan Karimunjawa yang telah mendukung kegiatan ini, dan enumerator yang telah mengambil data hasil tangkapan ikan di Taman Nasional Karimunjawa.

\section{DAFTAR PUSTAKA}

Alamsyah AS, Sara L, Mustafa A. 2013. Studi Biologi Reproduksi Ikan Kerapu Sunu (Plectropomus areolatus) pada Musim Tangkap. Jurnal Mina Laut Indonesia. 01: 73-83.

Arreguin-Sanchez F, Pitcher TJ. 1999. Catchability Estimates and Their Application to the Red Grouper (Epinephelus morio) Fishery of the Campeche Bank, Mexico. Fishery Bulletin. 97: 746-757.

Ault J, Smith SG, Monaco ME, Appeldoorn RS. 2008. Length-based Assessment of Sustainability Benchmarks for Coral Reef Fishes in Puerto Rico. Environmental Conservation. 35: 22-23.

Badrudin M. 2015. Pedoman Teknis Estimasi Spawning Potential Ratio (SPR) dalam Ghofar A, P. Martosubroto, Wudianto. Protokol Pengkajian Stok Sumber Daya Ikan: Komisi Nasional Pengkajian Stok Sumber Daya Ikan (pp. 65-80). Jakarta: Pusat Penelitian dan Pengembangan Perikanan, Badan Penelitian dan Pengembangan Kelautan, Kementrian Kelautan dan Perikanan.

Beverton RJH. 1992. Patterns of Reproductive Strategy Parameters in Some Marine Teleost Fishes. Journal of Fish Biology. 41: 137-160.

Beverton RJH, Holt SJ. 1959. A Review of The Lifespan and Mortality Rates of Fish in Nature, and Their Relation to Growth and Other Physiological Characteristics. Ciba Foundation Colloquia on Ageing. 5: 142180.

Blackhart K, Stanton DG, Shimada AM. 2006. NOAA Fisheries glossary. NOAA Technical Memorandum NMFS-F/SPO-69. National Oceanic and Atmospheric Administration [internet]. Silver Spring, Maryland. Tersedia pada: http://ejournalbalitbang.kkp.go.id/index.php/jppi/article/ view/244.

Brusher JH, Schull J. 2009. Non-lethal Age Determination for Juvenile Goliath Grouper Epinephelus itajara from Southwest Florida. Journal Endangered species Research. 7: 205-212.

Bullock LH, Murphy MD, Godcharles MF, Mitchell ME. 1992. Age, Growth, and Reproduction of Jewfish, Epinephelus itajara, in the Eastern Gulf of Mexico. Fishery Bulletin. 90: 243-249. 
Burton ML. 2002. Age, Growth and Mortality of Mutton Snapper, Lutjanus analis from the East Coast of Florida, with a Brief Discussion of Management Implications. Fisheries Research. 59: 31-41.

Campbell SJ, Kartawijaya T, Yulianto I, Prasetia R, Clifton J. 2013. Co-management Approaches and Incentives Improve Management Effectiveness in the Karimunjawa National Park, Indonesia. Marine Policy. 41: 72-79.

Catalano MJ, Allen MS. 2010. A Size-ang-ageStructured Model to Estimate Fish Recruitment, Growth, Mortality, and Gear Selectivity. Fisheries Research. 105: 38-45.

Chiappone M, Sluka R, Sealey KS. 2000. Groupers (Pisces: Serranidae) in Fished and Protected Areas of the Florida Keys, Bahamas and Northern Caribbean. Marine Ecology Progress Series. 198: 261272.

DesRoisers NJD. 2011. Growth and Maturation of Plectropomus spp. in the Saudi Arabian Red Sea. Thesis. King Abdullah University of Science and Technology. Thuwai, Kingdom of Saudi Arabia.

Effendie MI. 2002. Biologi Perikanan. Edisi Revisi. Yogyakarta: Pustaka Nusa Tama. $161 \mathrm{p}$.

Elevati M, Aditya TW. 2001. Biologi Kerapu. Lampung: Balai Budidaya Laut Lampung. Departemen Kelautan dan Perikanan.

Ferreira BP, Russ GR. 1994. Age Validation and Estimation of Growth Rate of the Coral Trout, Plectropomus leopardus (Lacepede 1802) from Lizard Island, Northern Great Barrier Reef. Fishery Bulletin. 92: 46-57.

Ferreira BP. 1993. Reproduction of the Inshore Coral Trout Plectropomus maculatus (Perciformes: Serranidae) from the Central Great Barrier Reef, Australia. Journal of Fish Biology. 42(6): 831-844.

Froese R, Binohlan C. 2000. Empirical Relationships to Estimate Asymptotic Length, Length at First Maturity and Length at Maximum Yield Per Recruit in Fishes, with a Simple Method to Evaluate Length Frequency Data. Journal of Fish Biology. 56: 758-773.

Grandcourt EM, Al Abdessalaam TZ, Francis F, Al Shamsi. 2005. Population Biology and Assessment of the Orange-spotted grouper, Epinephelus coioides (Hamilton,
1822) in the Southern Arabian Gulf. Fisheries Research. 74: 55-68.

Heemstra PC, Randal JE. 2005. FAO Species Catalogue. Vol 16. Grouper of the World. (Family Serranidae, Subfamily Epinephelinae). An Annoted and Illustrated Catalogue of the Grouper and Lyretail Species Known to Date. Rome: FAO Fisheries Synopsis.

Hernandez A, Seijo JC. 2003. Spatial Distribution Analysis of Red Grouper (Epinephelus morio) Fishery in Yucatan Mexico. Fisheries Research. 63: 135-141.

Hordyk A, Ono K, Valencia S, Loneragan N, Prince J. 2014. A Novel Length-Based Empirical Estimation Method of Spawning Potential Ratio (SPR), and Tests of its Performance, for Small-scale, Datapoor Fisheries. ICES Journal of Marine Science. 2-15.

Hurtado EG, Puelles RCP, Salvador E, Cota, L, Yanez AAG, Garcia VM, Rosa RB. 2005. Historical Biomass, Fishing Mortality, and Recruitment Ternds of the Campeche Bank Red Grouper (Epinephelus morio). Fisheries Research. 71: 267-277.

Kartawijaya T, Prasetia R, Yulianto I. 2007. Laporan Teknis: Monitoring Pendaratan Ikan Hasil Tangkapan Berbasis Masyarakat di Karimunjawa (2005-2007). Bogor, Indonesia: Wildlife Conservation Society.

King M. 1995. Fisheries Biology: Assesment and Management. United Kingdom: Black Well Science Ltd.

Landu A. 2013. Pertumbuhan Laju Eksploitasi dan Reproduksi Ikan Kerapu Sunu (Plectropomus leopardus) di Perairan Kabupaten Kolaka Sulawesi Tenggara [tesis]. Bogor: Institut Pertanian Bogor.

Mamauag SS, Donaldson TJ, Pratt VR, McCullough B. 2000. Age and Size Structure of the Leopard Coral Grouper, Plectropomus leopardus (Serranidae: Epinephelinae), in the Live Reef Fish Trade of the Philippines. Proceedings 9th International Coral Reef Symposium, Bali, Indonesia 23-27 October 2000, Vol. 1.

Manickchand-Heileman SC, Phillip DAT. 2000. Age and Growth of the Yellowedge Grouper, Epinephelus flavolimbatus, and the Yellowmouth Grouper, Mycteroperca interstitialis, off Trinidad and Tobago. Fishery Bulletin. 98: 290-298. 
Mildenberger TK, Taylor MH, Wolff M. 2017. TropFishR: an R Package for Fisheries Analysis with Length Frequency Data. Working paper. 1-8.

Nelson ME, Vallierre KW, Deleveaux. 2007. The Bahamas Nassau Grouper (Epinephelus striatus) Fishery-two Assessment Methods Applied to a Data Deficient Coastal Population. Fisheries Research. 87: 17-27.

Pauly D. 1982. Studying Single-species Dynamics in a Tropical Multispecies Context. D. Pauly \& G. I. Mutphy (cds): Theory and Management of Tropical Fisheries, pp. 33-70. ICLARM Conf. Proc. 9. ICLARM, Manila.

Pauly D. 1984. Some Simple Methods for Tropical Fish Stock. FAO Fish. Tech. Pap. (243):52 pp. French and Spanish.

Prasetya R. 2010. Potensi dan Laju Eksploitasi Sumber Daya Ikan Kerapu di Perairan Teluk Lasongko Kabupaten Buton Sulawesi Tenggara [tesis]. Bogor: Institut Pertanian Bogor.

Rochet MJ, Trenkel VM. 2003. Which Community Indicators Can Measure the Impact of Fishing? A Review and Proposals. Canadian Journal of Fisheries and Aquatic Sciences. 60: 86-99.

Sadovy YJ. 2005. Troubled Times for Trysting Trion: Three Aggregating Groupers in the Live Reef Food-Fish Trade. SPC Live Reef Fish Information Bulletin. 14: 3-6.

Sadovy YJ, Donaldson TJ, Graham TR, McGilvray $P$, Muldoon GJ, Phillips MJ, Rimmer MA, Smith A, Yeeting B. 2003. The Live Reef Food Fish Trade: While Stocks Last. Asian Development Bank, Manila, 147.

Sadovy Y, Figueroa M, Roman A. 1992. Age and Growth of Red Hind Epinephelus guttatus in Puerto Rico and St. Thomas. Fishery Bulletin. 90: 516-528.

Sanchez FA. 2000. Octopus-red Grouper Interaction in the Exploited Ecosystem of the Northern Continental Shelf of
Yucatan, Mexico. Ecological Modelling. 129: $119-129$

Sitepu FG. 2007. The Fecundity, Gonad, and Sex Reversal of Coral Trout, Plectropomus leopardus from the Water of Spermonde Archipelago, South Sulawesi. Journal of Biological Science. 17(2): 100-107.

Sparre P, Venema SC. 1999. Introduksi Pengkajian Stok Ikan Tropis. Jakarta: Kerjasama FAO dan Pusat Penelitian dan Pengembangan Perikanan.

Sudirman MY, Karim. 2008. Ikan Kerapu (Biologi, Eksploitasi, Manajemen dan Budidayanya). Sulawesi Selatan: Yasrif Watampone, 98 pp.

Utojo, Tonnek S, Suharyanto A, Marsam. 1999. Studi Bioekologi Ikan Kerapu di Perairan Pantai Barat Sulawesi Selatan. Jurnal Penelitian Perikanan Indonesia. 5(1): 3137.

Widodo J, Suadi. 2006. Pengelolaan Sumber daya Perikanan Laut. Yogyakarta: Gadjah Mada University Press.

Widodo MS. 2006. Deferensiasi Gonad/Seks (Hermaprodit protogyni) pada Ikan Kerapu Lumpur (Epinephelus coiodes Hamilton) pada Kisaran Berat Tubuh yang Berbeda di Perairan Tanjung Luar, Lombok Timur, NTB. Jurnal Protein.13(2): 168-171.

Yin X. 2014. Sustainability of Coral Trout, Plectropomus leopardus, Fisheries in the Philippines and Indonesia [thesis]. University of Hong Kong.

Yulianto I, Hammer C, Wiryawan B, Palm HW. 2015. Fishing-induced Groupers Stock Dynamics in Karimunjawa National Park, Indonesia. Fisheries Science. 81: 417432.

Yulianto, I., Wiryawan, B., \&Taurusman, A. A. 2013. Responsible Grouper Fisheries in Weh Island, Aceh Province, Indonesia. Galaxea Journal of Coral Reef Studies. 269-276. 